\title{
LES UNITATS FRASEOLÒGIQUES I L'ORALITAT FICCIONAL EN LA NARRATIVA DE TONI CUCARELLA
}

\author{
IDIOMS AND FICTIONAL ORALITY IN TONI CUCARELLA'S NARRATIVE
}

\author{
Pelegrí Sancho Cremades \\ Universitat de València, España \\ pelegri.sancho@uv.es \\ https://orcid.org/0000-0001-8004-1950
}

\section{Resum}

En aquest article s'estudien les unitats fraseològiques en quatre obres de Toni Cucarella en relació amb l'oralitat ficcional. La tradició d'estudis sobre l'oralitat ficcional analitza els recursos que evoquen l'oralitat en textos escrits o audiovisuals. Entre aquests recursos, en els darrers anys s'ha destacat la importància de certes unitats fraseològiques que són pròpies de la llengua oral i, en aparéixer en textos escrits, evoquen la llengua oral, com un mitjà per caracteritzar de manera versemblant els personatges.

Analitzem la recurrència de les unitats fraseològiques $\mathrm{i}$ els motius que poden explicar aquesta recurrència. Les unitats fraseològiques més recurrents són les locucions verbals i les locucions adverbials. Es poden adduir diverses raons d'aquesta recurrència. La recurrència d'una unitat fraseològica amb una marca diafàsica (informal o col-loquial, o vulgar) o diatòpica (dialectal) contribueix a l'oralitat ficcional

\begin{abstract}
This paper studies idioms in four of Toni Cucarella's works and their relation to fictional orality. The fictional orality studies tradition analyzes the resources that evoke orality in written or audiovisual texts. Among these resources, the importance of many idioms that are typical of oral language has been highlighted. When those idioms appear in written texts, they evoke oral language, as a means of plausibly characterizing the characters.

I will analyze the recurrence of idioms and the reasons for this recurrence. The most frequently recurring idioms are verbal idioms and adverbial idioms. Several reasons may be adduced for this recurrence. On the one hand, the recurrence of an idiom with a diaphasic (informal or colloquial, or vulgar) or diatopic (dialectal) mark contributes to the fictional orality of the story. On the other hand, a high recurrence of certain idioms has been found,
\end{abstract}

Para citar este artículo: Sancho Cremades, Pelegrí (2021). Les unitats fraseològiques i l'oralitat ficcional en la narrativa de Toni Cucarella. ELUA, 35: 257-278. https://doi.org/10.14198/ELUA2021.35.13

Recibido: 17/04/2020, Aceptado: 19/10/2020

(C) 2021 Pelegrí Sancho Cremades 
del relat. També trobem una alta recurrència de certes unitats fraseològiques que pertanyen a l'estàndard i són neutres quant al registre, sovint unitats fraseològiques poc prototípiques. A més, la recurrència de certes unitats fraseològiques és esperable en un gènere discursiu com és la narrativa, on és especialment freqüent la introducció d'accions o la modificació d'aquestes mitjançant complements circumstancials de manera, temps, etc. (unitats fraseològiques adverbials).

Finalment, pel que fa a l'oralitat ficcional, determinades locucions verbals, locucions adverbials, amb una marca diafàsica col-loquial o vulgar, així com els refranys evoquen l'oralitat en els diàlegs i, en menor mesura, en la narració en primera persona.

PARAULES CLAU: fraseologia catalana; oralitat ficcional; narrativa; valencià col loquial; Toni Cucarella. which belong to the standard use of language and are register-neutral. They often are poorly prototypical idioms. The recurrence of certain idioms is expected in the discursive genre narrative, in which the introduction of actions or modification of these through circumstantial complements of manner, time, etc. (adverbial idioms) is especially frequent.

Finally, regarding fictional orality, certain verbal and adverbial idioms, with a diaphasic colloquial or vulgar mark, as well as proverbs, evokes the orality in the dialogues and, to a lesser extent, in the narration in first person.

KEYWORDS: catalan idioms; catalan proverbs; fictional orality; narrative; colloquial Valencian; Toni Cucarella.

\section{INTRODUCCIÓ ${ }^{1}$}

En aquest article presentem les unitats fraseològiques emprades en una selecció de l'obra de Toni Cucarella (Xàtiva, 1959). L'escriptor és autor d'una extensa obra narrativa, que inclou novel $\cdot$ les $\mathrm{i}$ col·leccions de contes. La major part de la seua obra està ambientada a la comarca de la Costera.

Adoptem una concepció ampla de la fraseologia ${ }^{2}$, que inclou des de les locucions fins als refranys, si bé amb algunes exclusions ${ }^{3}$. En aquesta concepció ampla de la fraseologia partim de la base que els trets que caracteritzen les unitats fraseològiques (repetició, fixació, institucionalització, significat idiomàtic, etc.) no necessàriament s'han de donar en totes les unitats fraseològiques perquè siguen considerades com a tals. El fet que presenten un gran nombre d'aquests trets definirà el prototip de les unitats fraseològiques. Així, no veure 's cera en les orelles 'no estalviar' és una unitat fraseològica prototípica per la repetició, fixació, institucionalització, significat idiomàtic -per via de metàfora-, etc. Tanmateix, hi ha també

1 Agraïm a Maria Josep Cuenca les observacions a una versió prèvia del present treball. Els errors que hi puga haver són de la nostra exclusiva responsabilitat.

2 Hem restringit el terme fraseologia per al nom de la disciplina, tal com recomanen Conca i Guia (2014), i hem intentat respectar els termes emprats pels diversos autors citats, fent els aclariments escaients.

3 No tractem extensament les fórmules oracionals, a les quals hem dedicat un altre treball (Sancho 2017). Tampoc no recollim les locucions conjuntives o prepositives, que no semblen jugar un paper en l'evocació de l'oralitat. A més, hem exclòs les comparacions fraseològiques (més ample que un palloc, conéixer més que la ruda), malgrat la importància que tenen en l'evocació de l'oralitat, perquè presenten un caràcter fraseològic controvertit; a més, es fa molt difícil distingir les comparacions fraseològiques o estereotipades (repetides, relativament fixades i institucionalitzades) de les comparacions que són creació de l'autor. El contrast amb les obres lexicogràfiques consultades no és un criteri fiable perquè aquestes no poden ser exhaustives a l'hora de recollir aquestes expressions, per tal com són un tipus d'unitats inestable, que es renova fàcilment (Luque 2005). Finalment, no ens hem ocupat tampoc de les col·locacions. 
unitats fraseològiques perifèriques, que presenten menys trets i l'estatus fraseològic de les quals pot ser qüestionable (per exemple, fer cas, té una fixació relativa i un significat semiidiomàtic, cf. més avall ${ }^{4}$ ).

El nostre corpus està format pel recull de narracions breus La lluna vista des de la terra (1997, sigla $L V T, 85$ pàgines) i les novel·les L'última paraula (1998, sigla $U P, 180$ pàgines), Els camps dels vençuts (2002, sigla CV, 184 pàgines) i Quina lenta agonia, la dels ametlers perduts (2003, sigla $Q L A, 230$ pàgines). Se n'ha fet un buidatge manual. També hem contrastat les unitats fraseològiques trobades amb algunes obres lexicogràfiques 5 . Quant al marc teòric, ens basem en la teoria sobre l'oralitat ficcional o fingida (Koch i Oesterreicher 1990; Koch i Oesterreicher 2007; Brumme 2008; Brumme i Resinger 2008; Brumme i Espunya 2012; Schellheimer 2016).

En $\S 2$ relacionarem l'ús de les unitats fraseològiques amb el concepte d'oralitat ficcional; en $\S 3$ direm algunes paraules sobre la presència de les unitats fraseològiques en la literatura; en $\S 4$ durem a terme una anàlisi quantitativa de les unitats fraseològiques trobades i aportarem les raons de la (relativa) recurrència d'aquestes. A continuació, posarem alguns exemples representatius de la contribució a l'oralitat ficcional de les unitats fraseològiques (§ 5). Finalment ( $§ 6)$, presentem les conclusions.

\section{LES UNITATS FRASEOLÒGIQUES I L'ORALITAT FICCIONAL}

En les darreres dècades s'han publicat nombrosos estudis sobre la recreació de l'oralitat en textos escrits o audiovisuals, el que es coneix com a oralitat ficcional o fingida, que compta ja amb llarga tradició, sobretot a Alemanya, però també a l'Estat espanyol. En aquesta tradició d'estudis s'analitza la presència de trets de l'oralitat en textos escrits, audiovisuals o multimodals i les restriccions que s'imposen en aquesta evocació de l'oralitat, en el benentés que un text escrit mai no pot equivaler per complet a un text oral. Koch i Oesterreicher $(1990 ; 2007)$ van presentar un model de variació lingüística, que es basa en els conceptes d'immediatesa i distància comunicativa. Existeix un continu concepcional entre els pols de la immediatesa i la distància comunicativa, de manera que entre tots dos se situen les realitzacions lingüístiques. Aquestes realitzacions lingüístiques poden manifestar una concepció parlada o escrita, independentment del mitjà, això és, si el canal de realització és la forma fònica o gràfica. Així doncs, un text escrit pot exhibir els trets del llenguatge parlat si va ser concebut sota determinades condicions comunicatives. Efectivament, la simulació del llenguatge parlat a través del mitjà escrit d'un text ficcional és una eina de la qual es valen els autors amb freqüència per a crear un discurs viu i autèntic, per a caracteritzar els personatges i conferir més realisme als diàlegs (Schellheimer 2016: 11).

Per tant, l'objecte d'estudi de l'oralitat ficcional té dos components: la relació amb el llenguatge parlat i el fet que és una creació per part de l'autor o el traductor. Brumme i Espunya (2012) defineixen de la següent manera el concepte d'oralitat ficcional:

4 La presència en els diccionaris consultats ens ha guiat a l'hora d'incloure l'aplec com a unitat fraseològica, si bé hem incorporat també unitats fraseològiques no atestades en aquestes obres lexicogràfiques.

5 Hem consultat fonamentalment el DCVB (Diccionari català-valencià-balear d'Alcover i Moll), ESP (Diccionari de sinònims de frases fetes d'Espinal), el DNV (Diccionari normatiu valencià de l'Acadèmia Valenciana de la Llengua) i MAR (Diccionari de fraseologia (segles XVII-XXI) de Martí). Cf. bibliografia final per a les referències completes. 
We will call fictional orality in general any attempt to recreate the language of communicative immediacy in fictional texts, including both narrative and theatrical texts as well as audiovisual or multimodal texts. Fictional orality is not opposed to actual orality, but is conceived as a special technique which consists mainly of the evocation of certain characteristics of spoken communicative situations such as spontaneity, familiarity, face-to-face interaction or physical proximity. (2012: 13)

Quant al terme evocació, per a Coseriu, aquesta fa possible assenyalar alguna cosa mitjançant recursos lingüístics sense realment mencionar-la i d'aquesta manera contribueix al significat del text (Coseriu 1980: 92-137, citat per Brumme i Espunya 2012: 13-14).

Cal insistir en el fet que la imitació del llenguatge parlat mai no pot ser completa, sinó que es tracta sempre d'una simulació: “[...] es el autor del texto, o sea la conciencia lingüística del autor, la que selecciona ciertos rasgos considerados característicos de la lengua hablada" (Oesterreicher 2004: 756, citat per Schellheimer 2016: 23).

Pel que fa a les unitats fraseològiques, a parer de Schellheimer (2016: 78), hi ha una sèrie de trets d'aquestes que contribueix que gran nombre d'unitats fraseològiques evoquen l'oralitat. En primer lloc, mentre que els enunciats de la distància comunicativa manifesten un alt grau de planificació i són considerats, per tant, elaborats, les condicions comunicatives de la immediatesa afavoreixen, o fins i tot imposen, un grau de planificació molt escàs. Segons Schellheimer (2016: 79), a aquesta funció contribueixen els fraseologismes comunicatius ${ }^{6}$.

En segon lloc, un altre factor de la comunicació i un paràmetre concepcional rellevant segons Koch i Oesterreicher (1990; 2007) és la implicació emocional, val a dir, aquesta determina la concepció escrita o parlada del text. Els fraseologismes comunicatius, que intervenen en la realització d'actes comunicatius recurrents i que tenen una funció pragmàtica específica, contribueixen a l'oralitat ficcional per la seua expressivitat (Schellheimer 2016: 82).

Un aspecte, doncs, a tenir en compte a l'hora d'establir la relació entre les unitats fraseològiques i la llengua parlada és la funció expressiva i intensificadora de les expressions idiomàtiques. Existeix un ampli acord en el fet que l'ús d'aquestes unitats confereix expressivitat i emocionalitat a l'enunciat. Briz (1998: 120-123) esmenta algunes unitats fraseològiques com a recurs intensificador i, segons Vigara (1992: 134), l'ús de la fórmula estereotipada és "[...] si no uno de los más frecuentes sí el procedimiento más sonoro y contundente por el que el hablante expresa su actitud." .

Per exemple, la fórmula oracional Mort Pasqual li portaren l'orinal manifesta desaprovació del discurs previ. El DCVB recull la forma Després que fonc mort Pasqual, li portaren l'orinal i en diu “[...] es diu referint-se als auxilis prestats fora de temps o quan ja no són útils." La rima i la metàfora delaten el seu caràcter fraseològic. En espanyol, la fórmula oracional equivalent és A buenas horas,(mangas verdes).També és fórmula oracional Això faltaria!

(1) -Vols que la tia els diga a les mongetes que facen un apartat per a misses teues...? -Això faltaria! Done-m'ho ara en diners i deixe's de misses i de romanços. Mort Pasqual li portaren l'orinal... Ara, ara vull disfrutar-ho jo, en vida... ( $C V$, p. 73 )

6 Aquesta autora considera fraseologisme i unitat fraseologica termes sinònims; en conseqüència, parla de fraseologismes comunicatius per referir-se a les fórmules oracionals, terme preferit per nosaltres (cf. Sancho 2017). A grans trets, les fórmules oracionals són unitats fraseològiques equivalents a l'oració que s'associen a una determinada funció pragmàtica: Para el carro! L'autora també fa servir expressions fixes o idiomàtiques com a equivalents d'unitat fraseologica. 
Fleischer (1982: 164-165, citat en Schellheimer 2016: 84) identifica quatre fonts d'aquesta expressivitat que una unitat fraseològica pot transmetre: la idiomaticitat, les propietats foneticorítmiques (com ara rimes i al·literacions), la duplicació de sinònims o antònims, així com els elements únics i les anomalies sintàctiques. A més a més, moltes expressions fraseològiques contenen un element hiperbòlic, que n'augmenta el valor expressiu (menjar-se les mans a mossos 'tindre gran nerviosisme i inquietud' (DNV), caure l'ànima als peus 'Tindre un gran desengany' (DNV)).

Finalment, Schellheimer (2016: 88-89) assenyala que les unitats fraseològiques freqüentment duen marques estilístiques que difereixen de la norma lingüística i que s'associen amb variants diatòpiques, diastràtiques o diafàsiques. Les fórmules comunicatives i altres fraseologismes s'empren per a recrear les converses orals quotidianes. D'aquesta manera, les unitats fraseològiques poden evocar una parla autèntica i idiomàtica, sovint també estereotipada, darrere de la qual es poden amagar els pensaments i actituds igualment estereotipats de qui parla. En (2), s'empren unitats fraseològiques clarament evocadores de l'oralitat en un fragment de diàleg: sap què li he de dir és una fórmula oracional que introdueix un fragment nou de discurs, tot sovint una conclusió; amb les mans netes és una locució adverbial i menjar-se el cacau pelat $i$ bo una locució verbal. Les unitats fraseològiques que apareixen en (2) pertanyen al registre col·loquial (varietat diafàsica) i no serien adients en registres formals.

(2) -Sap què li he de dir, tia Ramona? Demà, que vinguen les seues monges i li torquen elles la merda, perquè servidora, ser-vi-do-ra, no li ha netejat el cul a vosté barat a les corfes, $\mathrm{i}$ ara que vinguen forasters amb les mans netes i es mengen el cacau pelat $\mathrm{i}$ bo, tot molletes. $(C V$, p. 71$)$

Toni Cucarella és conscient que ell, entre altres autors catalans, ha anat incorporant un lèxic procedent en bona part de la llengua oral col·loquial. Cucarella defensa l'ús d'una llengua viva, és a dir, col·loquial, per tal de caracteritzar els personatges de la seua literatura (Cucarella 2002: 128). Quant a la seua varietat lingüística, afirma: "La meua "varietat lingüística" és la que es parla a la comarca de la Costera, i és a partir del lèxic d'aquesta contrada que jo he realitzat la tasca de bastir la meua llengua literària." (Cucarella 2002: 128).

\section{LES UNITATS FRASEOLÒGIQUES EN LA LITERATURA}

En aquest apartat, sense ànim d'exhaustivitat ${ }^{7}$, recollim algunes contribucions sobre la presència d'unitats fraseològiques en textos literaris des de diferents perspectives. Conca (1996), a propòsit de la fraseologia emprada per Enric Valor, ha assenyalat la importància de les unitats fraseològiques en la cohesió del text literari:

\footnotetext{
7 Presentem les aportacions que hem trobat en la nostra documentació respecte de la presència de les unitats fraseològiques en la literatura, en especial en l'àmbit del català, però no exclusivament. El tema s'ha tractat àmpliament. D'acord amb Schellheimer (2016: 66-67), les funcions de la fraseologia en la literatura han estat objecte d'estudi de diverses investigacions. Aquestes s'han concentrat en l'anàlisi dels fraseologismes en una obra determinada o en l'obra d'un autor particular; també en diferents èpoques o gèneres literaris. Moltes d'aquestes obres se centren en algun tipus especial de fraseologisme. Schellheimer cita algunes obres que tracten la qüestió en l'àmbit alemany (Schellheimer 2016: 66, n. 12).
} 
[...] aquestes expressions que, a més de donar vivesa i color al maneig de la llengua col·loquial, funcionen com a peces de cohesió sintàctica, lèxica o pragmàtica; com a resum argumental o motiu d'una rondalla; com a citació amb intenció argumentativa; com a exemple amb valor analògic $i$, sobretot, com a marques culturals d'un procès històric que s'ha arrelat a la llengua viva dels parlants muntanyesos d'aquestes contrades i que té el seu paral·lelisme amb els parlants d'altres espais muntanyencs del nostre país. [...] (1996: 48)

Zuluaga (1997), per la seua part, s'ha ocupat de les funcions que exerceixen les unitats fraseològiques en els textos literaris. L'autor identifica quatre funcions inherents als fraseologismes ${ }^{8}$ que depenen de les propietats d'aquestes unitats i que es despleguen en el discurs literari.

1) La funció fraseològica és una “[...] función textual inherente, básica, peculiar y común a todas estas unidades" (Zuluaga 1997: 631). Consisteix a facilitar i simplificar al màxim tant la formulació del missatge per part de l'autor com la recepció per part del lector o oient, dient alguna cosa mitjançant una construcció lingüística ja feta i coneguda en la comunitat respectiva.

2) La connotació o evocació és inherent a les unitats fraseològiques amb marques diasistemàtiques, les quals, “[...] al ser empleades fuera de su medio propio, lo evocan. Este puede ser, una región, un nivel sociocultural o un ambiente determinado y constituye parte del contenido del signo, aunque no se refiera a rasgos del objeto o asunto designado" (Zuluaga 1997: 633).

3) La funció icònica "[...] consiste en presentar un contenido mediante una imagen concreta de orden visual. Tienen, pues, las unidades fraseológicas icónicas o figuradas un sentido literal, una imagen, y un sentido metafórico, idiomático o semiidiomático" (Zuluaga 1997: 634).

4) La funció ludicopoètica està relacionada amb els procediments fonoestilístics amb els quals moltes unitats fraseològiques estan configurades, com ara al·literacions, ritmes, paral·lelismes, repeticions, etc. (Zuluaga 1997: 635).

El que Zuluaga denomina la funció fraseològica, que presenta un parentiu amb el concepte d'economia lingüística, afavoreix l'ús de les expressions fixes en la llengua parlada, ja que aquestes ofereixen la possibilitat de realitzar actes comunicatius recurrents o rutines comunicatives sense necessitat de planificació (Stein 2007: 229, citat en Schellheimer 2016: 68). Així mateix, mitjançant els valors connotatius associats a una unitat fraseològica amb marca diasistemàtica, es pot evocar la parla idiosincràtica d'un personatge i així reforçar la seua caracterització o donar colorit local a la narració (Schellheimer 2016: 68). Un exemple cridaner del nostre corpus és el discurs de la prostituta del relat "La conversa", amerat d'unitats fraseològiques col·loquials pròpies del parlar de la Costera (3) 9 .

(3) Lo primer que vaig fer va ser dir-li-ho al Pere, ¡i el recabró em va espolsar que m'espavilara per aon poguera i avortara! Has sentit cantar el pollastre? Però, aguarda't, que entonses no era jo valenteta ni res. I aixina és que li retruque que ni pensar-ho, que d'avortar res de res, ¡que qui l'entorta se l'emporta o li posa un quiosquet!, que què volia dir això de mullar primer i en acabant jo sóc músic i me gite a les huit. (LVT, p. 70)

8 Zuluaga (1997) empra fraseologisme i unitat fraseologica com a sinònims.

$9 \quad$ Es tracta d'un relat en primera persona de la vida de la protagonista, una prostituta, que enregistra amb una gravadora el narrador. Hi ha una forta presència de recursos de col·loquialització, que no eviten les formes no normatives (castellanismes, dialectalismes, etc.), com es pot comprovar. 
Hi trobem els refranys Qui l'entorta se l'emporta o li posa un quiosquet i Jo sóc músic i me gite a les huit. Les fórmules oracionals Has sentit cantar el pollastre? i ni res ${ }^{10}$ també evoquen l'oralitat. Finalment, d'altres marques de l'oralitat ficcional són les interjeccions impròpies formades per més d'un mot, com aguarda't i ni pensar-ho.

Mitjançant la funció ludicopoètica de les unitats fraseològiques, l'ús d'expressions fixes en un text literari " "...] satisface el gusto natural del ser humano por el ritmo y la armonía de los sonidos [...]", i així “[...] confiere al discurso -incluso aunque el asunto sea melancólico- su nota de gracia y humor.” (Zuluaga 1997: 635). A més, determinades característiques sintacticoestilístiques, com ara paral·lelismes i rimes, també es presten per a dur a terme modificacions ocasionals de la unitat fraseològica i així crear efectes còmics o ajudar a conferir cohesió textual. Un aspecte important en l'ús de les unitats fraseològiques en els textos literaris és la seua contextualització, és a dir, la creació de relacions entre una unitat fraseològica i el text per mitjà de diversos procediments (Richter-Vapaatalo 2007: 68, citada en Schellheimer 2016: $74^{11}$ ).

Per la seua banda, Piquer s'ha concentrat en la relació entre les unitats fraseològiques emprades generalment i el seu ús en textos literaris. Piquer (2000) comenta l'aprofitament per part dels literats de les unitats fraseològiques en els següents termes:

La frase feta, sovint nascuda de la comunitat de parla, és aprofitada pel literat per construir la seua ficció i retorna al mateix àmbit d'on va sortir (Tristá, 1988). Aquest és un botó de mostra del funcionament de la semiosfera; la locució, la frase feta i la parèmia són el boomerang que es desplaça del context al text i a l'inrevés. El discurs narratiu es converteix, així, en un mecanisme d'intertextualització del llenguatge que es dóna en el context social alhora que basteix expressions que poden arribar a constituir-se en frases fetes. $(2000: 390-391)^{12}$

I, en una altre treball, parla del "reciclatge" de la fraseologia, en el sentit que l'ús de les unitats fraseològiques amb una finalitat estètica implica reutilitzar-les amb una voluntat diferent de l'habitual (2005: 63).

Ferrer i Salvador (2005) remarquen la importància de les unitats fraseològiques en la literatura, tot i que el que seria esperable, si atenem a la creativitat que caracteritza el

10 De les fórmules oracionals i les relacions amb les interjeccions impròpies que consten de més d'un mot ens hem ocupat en Sancho (2017). La tradició gramatical distingeix entre interjeccions pròpies, que són únicament interjeccions $(a h, e h)$ i les impròpies, resultat de la gramaticalització de sintagmes (a gosades; Mare de Déu, Senyor). Les interjeccions impròpies no són unitats fraseològiques, si bé evoquen clarament l'oralitat i mantenen relacions de semblança de família amb les fórmules oracionals. En efecte, si la distinció entre interjeccions impròpies que consten d'un únic mot i les fórmules oracionals, pluriverbals, és clara, resulta difícil de vegades distingir les fórmules oracionals de les interjeccions impròpies que consten de més d'un mot. Tant les interjeccions impròpies com les fórmules oracionals comparteixen la fixació, el significat idiomàtic, el valor pragmàtic, l'equivalència d'oracions i el caràcter gramaticalitzat. L'entonació, en general, permet distingir bona part de les interjeccions impròpies de les fórmules oracionals, però no sempre, ja que hi ha interjeccions impròpies que tenen una entonació enunciativa, i no exclamativa (a veure) i també hi ha fórmules oracionals amb entonació exclamativa (Para el carro!). És possible que la diferència es trobe en el grau de gramaticalització, més avançat en el cas de les interjeccions impròpies, en el benentés que per a alguns autors les interjeccions són també equivalents d'oracions (Cuenca 2011).

11 Sobre la contextualització de les unitats fraseològiques cf. Conca i Guia (2014).

12 L'autor parla de fraseologia com el conjunt de les unitats fraseològiques i hi distingeix les fórmules habituals en el discurs, incloses les rutinàries, les locucions, frases fetes i parèmies, i les combinacions de paraules habituals en una llengua i usades en un sentit metafòric (Piquer 2000: 389-390). 
discurs literari, seria la presència desautomatitzada; tanmateix, en el discurs literari es troben "[...] nombrosos recursos de convenció que fixen el discurs literari en clixés rebuts." (Ferrer i Salvador 2005: 9).

Per acabar, Conca i Guia (2014: 115), des d'un punt de vista general, han destacat la importància d'elaborar corpus fràsics ${ }^{13}$ d'autors concrets, per les següents raons. D'una banda, en relació amb la crítica literària, perquè l'inventari de les unitats fràsiques i unitats estilístiques d'una obra i el seu estudi ajuden a conéixer l'estil de l'autor al temps que ens proporcionen informacions precises per a la determinació de fonts, intertextualitzacions, datacions, etc. D'altra banda, perquè així podem aportar a la disciplina fraseològica exemples reals d'unitats fràsiques en context. Finalment, per conéixer de manera més completa les realitzacions i potencialitats expressives de la llengua.

\section{LES UNITATS FRASEOLÒGIQUES EN L'OBRA DE TONI CUCARELLA: ANÀLISI QUANTITATIVA}

Presentem el nombre d'unitats fraseològiques trobades en el nostre corpus segons les categories. Les locucions verbals i les adverbials són les més freqüents.

Taula 1. Recurrència de les unitats fraseològiques segons les categories

\begin{tabular}{|l|l|}
\hline Categoria d'unitat fraseològica & Unitats fraseològiques enregistrades \\
\hline Locucions verbals & 332 \\
\hline Locucions nominals & 59 \\
\hline Locucions adjectives & 36 \\
\hline Locucions adverbials & 228 \\
\hline Refranys & 46 \\
\hline
\end{tabular}

Trobem 699 unitats fraseològiques diferents en un conjunt de 679 pàgines buidades, la qual cosa dona una mitjana de 1,02 unitats fraseològiques per pàgina. Ara bé, si tenim en compte el conjunt total d'ocurrències, n'obtenim 1318; entre les 679 pàgines buidades, donaria una mitjana de 1,94 unitats fraseològiques per pàgina. S'ha de tenir en compte que per a obtenir xifres exactes de la freqüència caldria comptabilitzar el conjunt dels mots emprats en els textos i les categories a què pertanyen (noms, adjectius, verbs, adverbis) i veure la freqüència d'ús per pàgina, tasca que no hem dut a terme. Per aquesta raó, en la resta de l'article preferim emprar el terme recurrència més que no pas freqüència, que donaria compte d'aquest valor comparatiu que no hem contemplat. De tota manera, si considerem les dades aportades per Hanks (2000, cf. més avall), que atesta una escassíssima freqüència d'unitats fraseològiques molt conegudes en anglés a partir de dades de corpus, podríem dir que 1,94 ocurrències d'unitats fraseològiques per pàgina és una presència destacada-segurament més per la prominència cognitiva que presenten moltes d'aquestes, que explicarem després, que no pas perquè siguen gaire freqüents-, però moderada ${ }^{14}$.

13 Els autors empren fràsic (corpus fràsic, unitat fràsica) on més comunament trobaríem fraseològic i reserven el terme fraseologia per al nom de la disciplina.

14 El mateix autor afirma no tenir una intenció "conservacionista" sobre el lèxic dialectal en general, tot incloent-hi les unitats fraseològiques: "No és la meua intenció fer arqueologia lèxica, com tampoc fer de les meues 
Les unitats fraseològiques no són recurrents: la major part de les unitats fraseològiques presenten una única ocurrència. A tall d'exemple, en la taula 2 presentem les recurrències de les locucions verbals, les unitats fraseològiques més freqüents del corpus, entre 1 i 4 recurrències ${ }^{15}$. En general, aquesta manca de recurrència de les unitats fraseològiques concretes demostra la riquesa i varietat d'unitats fraseològiques emprades en l'obra de Cucarella.

Taula 2. Recurrència de les locucions verbals (1-4)

\begin{tabular}{|l|l|}
\hline Recurrències & Unitats fraseològiques \\
\hline 1 & 253 \\
\hline 2 & 44 \\
\hline 3 & 18 \\
\hline 4 & 8 \\
\hline
\end{tabular}

Les generalitzacions que puguem fer sobre la recurrència de les unitats fraseològiques en l'obra de Cucarella analitzada no són extrapolables a la llengua oral col·loquial actual de la Costera $^{16}$. Hi ha una tradició d'estudis sobre la llengua col·loquial i sobre les unitats fraseològiques que considera que aquestes són molt freqüents en la llengua oral col·loquial, fins al punt que per a alguns autors la freqüència d'ús seria un dels trets definitoris de les unitats fraseològiques (Corpas 1996: 21; García-Page 2008: 32) Tanmateix, a parer de Burger (1998: 15-16) és difícil comprovar de manera fiable la freqüència d'ús d'una expressió i Fleischer (1982: 64) apunta que aquesta característica no pot ser criteri necessari de definició, per tal com hi ha fraseologismes poc freqüents (citats per Schellheimer 2016: 42). Aquesta tradició ha estat qüestionada, a més a més, en analitzar corpus orals reals ${ }^{17}$. Hanks (2000) analitza corpus de l'anglés (no n'especifica la tipologia) i observa que les unitats fraseològiques en anglés són molt poc freqüents; per exemple, red herring 'pista falsa, maniobra distractiva' presenta 74 ocurrències en el British National Corpus, que conté 100.000.000 de mots. L'autor afirma: "[...] 74 occurrences in 100.000 .000 may sound quite rare, but this is actually one of the more frequent idioms." (Hanks 2000: 311). Encara menys freqüent és l'idiom to kick the bucket 'morir', que en el mateix corpus presenta només dues ocurrències genuïnes, tot i ser un idiom que se cita sovint en parlar de les unitats fraseològiques de l'anglés. Per a l'autor citat, això voldria dir que un parlant corrent empraria, veuria o escoltaria la unitat fraseològica en qüestió una sola vegada cada cinc o deu anys. Ara bé, l'autor matisa que la freqüència en els corpus orals és vàlida per als corpus en qüestió i no es pot extrapolar a la llengua real sense justificació (Hanks 2000: 314). Altres estudis han constatat una baixa freqüència de les locucions verbals (Penadés 2004), dels refranys (Penadés 2006) i de les fórmules oracionals (Núñez 2016) a partir de corpus orals.

obres una imitació més o menys actualitzada de la Rondalla de Rondalles, enfilant arreu manera frases i paraules en major o menor perill d'extinció" (Cucarella 2002: 28).

15 Com es pot veure en la taula 2 i en la taula 3, que la completa, a mesura que augmenta la recurrència, trobem menys unitats fraseològiques, fet que demostra la varietat en l'ús d'unitats fraseològiques que comentàvem.

16 L'ús real segurament se sotmet a variabilitat sociolingüística, depenent de l'edat, el nivel d'instrucció, la variació diafàsica, etc. Tanmateix, no coneixem estudis en català que atenguen a aquests paràmetres.

17 Cf. sobre aquesta qüestió Ruiz (1996), si bé constata que bona part dels estudis tradicionals sobre l'espanyol col·loquial es basen en textos escrits i defensa la necessitat de basar-se en corpus orals reals per a estudiar les unitats fraseològiques $\mathrm{col} \cdot$ loquials. 
Tanmateix, malgrat la baixa freqüència que els diversos estudis ressenyats atribueixen a les unitats fraseològiques a partir de l'anàlisi de corpus reals, Hanks (2000: 320) considera que són cognitivament prominents. L'autor no explica l'afirmació, però pot referir-se al fet que destaquen sobre el discurs habitual per les especificitats que presenten, especialment la institucionalització i la presència de figures retòriques en moltes d'aquestes. Ja Jakobson (1964), en parlar de la funció poètica del llenguatge, considerava que les figures retòriques, en el seu origen, afavorien la recordabilitat i eren un mitjà per a emmagatzemar la informació en cultures preliteràries, que no coneixien l'escriptura. En efecte, gran part de les unitats fraseològiques presenten figures retòriques formals (isosilabisme, rimes, paral·lelismes, etc.) i semàntiques (sobretot, la metàfora, però també la metonímia i la hipèrbole, entre moltes altres), que n'afavoreixen la recordabilitat. En el mateix sentit, les figures retòriques de caràcter semàntic fan l'enunciat més expressiu, el modalitzen, per tal com manifesten la subjectivitat del parlant ${ }^{18}$, i donen plasticitat al llenguatge ${ }^{19}$.

Des de la perspectiva del receptor, Timofeeva (2012: 147-148) fa notar que les unitats fraseològiques expressives es creen per “impactar" l'oient i cridar-ne l'atenció. A més, els parlants semblen tenir una consciència metalingüística de les unitats fraseològiques, això és, tenen una intuïció, sobretot en les unitats fraseològiques que fan servir figures retòriques semàntiques, que es tracta d'expressions peculiars fixades per l'ús i que no tenen significat literal, tal com demostra l'existència de les fórmules metadiscursives (Salvador 1995) o d'inserció (Conca i Guia 2014). Per exemple, en els següents textos, procedents de converses orals col·loquials enregistrades, trobem casos d'aquestes fórmules d'inserció: a (4), això diuen -davant la reacció de $\mathrm{B}$, que interpreta Ham anat a Roma i no ham vist al Papa com una expressió literal; que dic jo, a (5), marca anficòs de marge com a unitat fraseològica.

(4) A: ham d'anar a Llanera un dia (()) lo mal serà $\rightarrow$ n'hi ha un camí pac amunt/ em pense que és el cementeri o el calvari/ no ho sé/ aixina és que ham anat a Roma i no ham vist al Papa

B: A ROMAA?

A: dona/ això diuen

$\mathrm{B}: \mathrm{Ah} ! /$ ja d(e)ia jo/20

(5) A: [n- eella no er- eera un anficòs/ d'estos de marge/ que dic jo]

C: qui?

A: [que no sabien ni a on es caïa la cà-]

Salvador (1995), per la seua part, ha assenyalat el valor de les unitats fraseològiques com a senya d'identitat, això és, com a signe en què es reconeix una comunitat lingüística, cultural i nacional. Entenem que comunitat lingüistica enclou els parlants d'una llengua, però també els usuaris de les varietats i registres.

18 Aquest caràcter expressiu de les unitats fraseològiques fa que siguen adients al registre col·loquial, el qual, com és ben establert en la tradició d'estudis sobre la llengua col-loquial, es caracteritza per l'expressivitat (subjectivitat) (cf. entre nosaltres Payrató 1988).

19 Cuenca (2008: 46) inclou entre els mecanismes de modalització de naturalesa pragmàtica les unitats fraseològiques i algunes figures retòriques -metàfora, comparació, hipèrbole, ironia.

20 El parlant A és una persona adulta i el parlant B la seua neta petita, una xiqueta. 
Des d'un punt de vista pragmàtic, Timofeeva (2012) ha destacat que les unitats fraseològiques tenen un caràcter marcat, d'acord amb l'heurística $\mathrm{C}$ del model neogriceà de Levinson (2004). Segons aquesta heurística, que es relaciona amb la máxima de manera de Grice, "El que es diu d'una manera inusual, no és normal: o un missatge marcat indica una situació marcada." (citat per Timofeeva 2012: 108).

En conclusió, tot i que es podria pensar que les unitats fraseològiques són poc recurrents, existeixen nombroses raons per considerar-les cognitivament prominents, en el sentit que destaquen dins del discurs tant des de la perspectiva de l'emissor com del receptor, si més no aquelles que presenten figures retòriques $i$, en conseqüència, tot sovint significat idiomàtic. En $\S 5$ veurem alguns exemples d'unitats fraseològiques contextualitzades que tenen aquest caràcter prominent des d'un punt de vista cognitiu.

En el següent quadre hem seleccionat aquelles unitats fraseològiques que presenten una recurrència igual o major que 5. Cal tenir en compte que aquesta recurrència pot manifestar les preferències de l'autor, conscients o no, però segurament passa desapercebuda al lector, ja que, per exemple, cinc recurrències en quatre obres literàries (i encara un nombre major de recurrències) seria probablement imperceptible per a un lector fins i tot en el cas que haja llegit totes quatre obres narratives.

Taula 3 .

\begin{tabular}{|c|c|}
\hline CATEGORIA I RECURRÈNCIA & UNITATS FRASEOLÒGIGUES \\
\hline \multicolumn{2}{|l|}{ A) LOCUCIONS VERBALS } \\
\hline 5 & $\begin{array}{l}\text { escampar el poll 'Anar-se'n, fugir o escapar-se' }(D N V) \text {, } \\
\text { fer falta 'Caldre, ser necessari' (DNV), fer goig 'Causar, } \\
\text { algú o alguna cosa, satisfacció per la seua bellesa o la seua } \\
\text { abundància' (DNV), fer l'efecte 'Paréixer, semblar' (DNV), } \\
\text { fer-se càrrec 'Encarregar-se'n, ocupar-se'n' (DNV), girar } \\
\text { cua 'Girar l'esquena per a anar-se'n', plantar cara 'Fer-li } \\
\text { front o afrontar-la sense acovardir-se' (DNV), tocar el testet } \\
\text { 'Molestar, emprenyar, destorbar' (DNV), valer la pena } \\
\text { 'Compensar l'esforç' (DNV). }\end{array}$ \\
\hline 6 & $\begin{array}{l}\text { calfar-se el cap 'Fatigar-se mentalment, estudiant o } \\
\text { considerant alguna cosa, pensar, cavil·lar' }(D N V) \text {, pegar a } \\
\text { fugir 'Fugir ràpidament' }(D N V) \text {. }\end{array}$ \\
\hline 8 & $\begin{array}{l}\text { fer cas 'Considerar-la important, digna de posar-hi atenció' } \\
(D N V) \text {, traure a una vora (eixir a una vora 'Superar una } \\
\text { dificultat o una etapa de desgràcies' }(D N V)) \text {. }\end{array}$ \\
\hline 9 & saber greu 'Saber mal' $(D N V)$. \\
\hline 12 & fer la guitza 'Molestar-lo, contrariar-lo, destorbar-lo' (DNV). \\
\hline 19 & estimar-se més 'Preferir' $(D N V)$ \\
\hline \multicolumn{2}{|l|}{ B) LOCUCIONS NOMINALS } \\
\hline 16 & fill de puta 'Persona menyspreable per la seua maldat' $(D N V)$. \\
\hline
\end{tabular}




\begin{tabular}{|c|c|}
\hline CATEGORIA I RECURRÈNCIA & UNITATS FRASEOLÒGIGUES \\
\hline \multicolumn{2}{|l|}{ C) LOCUCIONS ADJECTIVES } \\
\hline 5 & $\begin{array}{l}\text { de collons 'Molt bo, excepcional, que està molt bé' }(D N V) \text {, } \\
\text { de cos present 'Amb el difunt encara no enterrat' }(D N V) \text {, de } \\
\text { deveres 'De veres' (DNV) 'de veritat'. }\end{array}$ \\
\hline \multicolumn{2}{|l|}{ D) LOCUCIONS ADVERBIALS } \\
\hline 5 & $\begin{array}{l}\text { a corre-cuita 'Precipitadament, sense dedicar el temps } \\
\text { necessari' (DNV), a poquet a poquet (a poc a poc 'Lentament, } \\
\text { a espai' } D N V) \text {, amb prou faenes 'Difícilment, a penes }(D N V) \text {, } \\
\text { cara a cara 'Manifestament, l'un enfront de l'altre', de bat } \\
\text { a bat 'Obrint completament (una porta, una finestra)', 'sense } \\
\text { amagar res, sense cap reserva'(DNV), de gaidó 'Obliquament, } \\
\text { de costat' (DNV), en aquell entonses 'en aquell moment' }{ }^{21} \text {, } \\
\text { per res del món 'De cap manera' }(D N V) \text {. }\end{array}$ \\
\hline 6 & $\begin{array}{l}\text { cames em valguen 'salvant-se gràcies a les cames', de mala } \\
\text { veta 'de mal humor', de sol a sol 'des que surt el sol fins que } \\
\text { es pon' }(E S P) \text {. }\end{array}$ \\
\hline 7 & $\begin{array}{l}\text { a manta 'en abundància' (DNV), en va 'Inútilment, debades' } \\
(D N V) \text {. }\end{array}$ \\
\hline 8 & $\begin{array}{l}\text { a males penes 'Penosament' }(D N V) \text {, 'tot just; a penes' }(E S P) \text {, } \\
\text { a penes 'Quasi no' }(D N V) \text {. }\end{array}$ \\
\hline 9 & de bon mati' 'Molt matí' $(D N V)$ \\
\hline 10 & $\begin{array}{l}\text { de colp i volta 'De sobte' (DNV), de rabinada 'per impuls } \\
\text { violent, arravatadament' }(D C V B) .\end{array}$ \\
\hline 11 & a tothora 'Sempre, amb molta freqüència' $(D C V B)$. \\
\hline 12 & a muntó 'Molt (de)' (DNV). \\
\hline 14 & de seguida 'Sense tardar, immediatament' $(D N V)$. \\
\hline 20 & tot seguit 'Immediatament després' $(D N V)$. \\
\hline 22 & i tot ‘Fins i tot, inclús' $(D N V)$. \\
\hline 24 & de tant en tant 'De temps en temps, a intervals' $(D N V)$. \\
\hline 31 & tot d'una 'de seguida', 'de sobte' $(D N V)$. \\
\hline 42 & de sobte 'D'improvís, de colp, sense esperar-ho' $(D N V)$. \\
\hline
\end{tabular}

En línies generals, es pot observar que les unitats fraseològiques amb una recurrència major són neutres quant al registre ${ }^{22}$, no exhibeixen connotacions expressives $\mathrm{i}$ en alguns casos presenten un grau major de gramaticalització, per exemple, les locucions adverbials de seguida, tot seguit, de tant en tant, tot d'una.

21 Castellanisme, forma no normativa. Totes les ocurrències apareixen en el relat "La conversa", ja citat.

22 No hem trobat informació sobre la marca diafàsica, és a dir, quant al registre, en les obres lexicogràfiques consultades. Per tant, les valoracions quant a la marca diafàsica són nostres i ens hem basat, en línies generals i en els casos comentats, en Penadés (2013) i Sancho (2019). Cal tenir la prevenció que l'assignació d'una marca col·loquial-informal o vulgar a les unitats fraseològiques és molt controvertida entre els fraseòlegs i els lexicògrafs. Així es pot comprovar, per exemple, en la tradició lexicogràfica de l'espanyol (Penadés 2013). 
També són neutres quant al registre i no presenten connotacions expressives les locucions vebals fer cas, saber greu i estimar-se més. L'estatut fraseològic d'aquestes locucions verbals és dubtós, si bé són recollides pels diccionaris com a tals (les enregistra, per exemple, el $D N V$ ). Presenten un caràcter repetit i fixació, però aquesta és relativa, per tal com admeten la introducció de constituents, especialment quantificadors: fer molt de cas, no fer gens de cas, saber molt de greu, estimar-se molt més (cf. Penadés 2004). Si atenem als significats que aporta el $D N V$ d'alguns dels constituents, podríem dir que el significat és semiidiomàtic. Respecte de fer cas, la primera accepció que presenta el DNV de cas és "Fet, estat o circumstància que es produïx o que es pot produir. Hem de considerar tots els casos possibles. Quin cas que li ha passat!' (les altres accepcions no hi guarden cap relació). No sembla que el significat global de fer cas ('Considerar-la important, digna de posar-hi atenció' ) s'hi relacione directament, per l'aplicació de regles semàntiques regulars, si bé hi ha unitats fraseològiques que probablement en deriven ( ni cas és segurament elisió de no fer ni cas).

Quant a saber greu, el significat global 'saber mal, doldre' possiblement es relaciona amb l'accepció de greu "Que té molta importància en un sentit negatiu. Un accident greu. Una acusació greu.", però el sentit de saber greu no es dedueix directament del significat dels constituents com en una construcció creativa i podríem considerar-la una unitat fraseològica semiidiomàtica. Per exemple, no sembla que greu tinga el matís d' 'important' i saber, si es relaciona amb 'tenir gust', té un sentit metafòric. Quant a la fixació, presenta normalment el clític obligatòriament: Em sap greu que no vingues. De manera semblant, en el cas d'estimar-se més, el significat es relaciona amb l'accepció “Apreciar el valor o la importància (d'algú, d'algun animal o d'alguna cosa). Tots estimen la seua capacitat de treball. S'estima molt el seu gosset." Tanmateix, és un aplec fix (estimar apareix necessàriament amb els clítics -me, -te, etc. i més) i el significat sembla ser igualment semiidiomàtic, ja que implica una major abstracció en relació amb l'accepció literal ressenyada. La fixació relativa i el caràcter semiidiomàtic ens indueixen a pensar que són unitats fraseològiques que es troben en la perifèria de les unitats fraseològiques, és a dir, són unitats fraseològiques poc prototípiques. A més, són neutres quant al registre, cosa que explica la seua extensió d'ús, i no tenen una connotació expressiva; per tot plegat, és probable que no siguen tan prominents per al lector com, per exemple, aquelles unitats fraseològiques que presenten metàfores (o altres figures retòriques, com la hipérbole) i, per tant, un significat (més) idiomàtic, a més d'un caràcter més fixat i una connotació expressiva.

Així, per exemple, amb 8 recurrències, traure a una vora resulta més prominent cognitivament per tal com és una unitat fraseològica col·loquial, dialectal i amb un caràcter expressiu marcat (presenta una metàfora), cosa que no s'esdevé amb la unitat fraseològica fer cas, amb la mateixa recurrència, però neutra quant al registre, sense connotacions expressives, pertanyent a l'estàndard i poc prototípica -té un significat semiidiomàtic i admet modificacions: fer molt de cas, no fer gens de cas, com acabem de dir.

Farem alguns comentaris a continuació sobre les unitats fraseològiques que presenten una major recurrència d'acord amb les diferents categories ${ }^{23}$. Quant a les locucions verbals, fer la guitza, amb 12 recurrències, encara que de procedència vulgar (Piquer i Martín 2006: 308), té una posició ferma en l'estàndard. La locució verbal més recurrent, estimar-se més, amb 19 ocurrències és neutra quant al registre, fet que explica aquesta recurrència. A més,

23 Comentem aquelles unitats fraseològiques amb 10 recurrències o més. 
molt probablement és una locució poc prototípica, en el sentit que és semiidiomàtica i admet modificadors, com hem dit (estimar-se molt més).

La locució nominal més recurrent és fill de puta, amb 16 recurrències. Es tracta d'un insult, de caràcter marcadament vulgar i corrent en la parla col·loquial; contribueix, doncs, a l'oralitat ficcional del relat, si bé no compta amb una marca dialectal, ja que és pròpia del registre col·loquial de tots els dialectes.

Finalment, quant a les locucions adverbials, amb 10 ocurrències trobem de colp $i$ volta (estàndard, neutra quant al registre) i de rabinada (col·loquial i dialectal). Amb 11 ocurrències hi ha a tothora i, amb 12, a muntó, totes dues dialectals i col·loquials. La locució adverbial de seguida, amb 14 ocurrències, pertany a l'estàndard, i és neutra quant al registre, i caldria contemplar un altre factor, que és el gènere literari, la narrativa, ja que és una locució que introdueix accions successives; el mateix caldria dir de tot seguit, amb 20 ocurrències. Quant a la funció de certes unitats fraseològiques en la literatura, Piquer (2000) assenyala el següent: "[...] els formulismes de continuïtat o els de tancament de la ficció narrativa, són marcadors discursius d'utilitat evident en la disposició determinada per la macroestructura textual." (2000: 397).

En el nostre article hem distingit a grans trets entre les parts narratives i les dialogals (cf. § 5), però dins de les parts narratives especialment no hem contemplat la diferència entre seqüències narratives i descriptives, tal com es fa en la lingüística textual. Les seqüències narratives, presumiblement abundants en les obres analitzades, es caracteritzen per la presència de verbs d'acció, els quals poden ser modificats per complements circumstancials de temps, manera, etc. Aquest fet, en general, pot explicar la recurrència d'unitats fraseològiques adverbials. Especialment freqüents són aquelles que marquen la continuïtat, com hem vist en el cas de tot seguit, però no sols, com veurem a continuació.

La locució $i$ tot, amb 22 ocurrències, és col·loquial (enfront de l'estàndard fins $i$ tot i el culte àdhuc $)^{24}$. De tant en tant, amb 24 ocurrències, pertany a l'estàndard i és neutra quant al registre, i també modifica una acció com a complement circumstancial (esdevé amb una freqüència espaiada); per aquesta raó és esperable que aparega en seqüències narratives. Amb 31 ocurrències trobem la locució adverbial tot d'una ${ }^{25}$; pertany a l'estàndard. A més, modifica accions, cosa que la fa adient al gènere literari narratiu ${ }^{26}$. Una explicació semblant té la locució adverbial sinònima de sobte, amb 42 recurrències ${ }^{27}$. Cal dir que les formes $i$ tot, de tant en tant, tot d'una i de sobte presenten un grau de gramaticalització important que pot justificar també la seua alta recurrència, per tal com una de les conseqüències de la gramaticalització és l'augment de la freqüència d'ús.

24 Cal dir que la consideració de fins $i$ tot i la forma col-loquial $i$ tot com a adverbis és tradicional. Des d'altres punts de vista es considera un predeterminant amb un valor pragmàtic escalar. Així, en Lluís va comprar fins $i$ tot loteria de Nadal, Lluís va comprar loteria de Nadal $i$ tot es marca loteria de Nadal com una entitat que és extraordinari que es comprés, amb una determinada finalitat argumentativa, per exemple, demostrar que Lluís va fer moltes compres.

25 El DIEC (Diccionari de la llengua catalana de 1'Institut d'Estudis Catalans) aporta dues accepcions per a la locució adverbial tot d'una: en primer lloc, 'de sobte, tot seguit' i, en segon lloc, remet a de seguida.

26 Lorente (2002: 868) considera que és una locució adverbial amb funció de complement de mode que indica immediatesa.

27 Conca i Guia (2014: 201) estableixen una correlació entre la freqüència d'ús i l'estil d'un determinat autor, en especial per referència a les unitats estilístiques, però també en el cas d'unitats fràsiques que tenen una alta freqüència. Tanmateix, no trobem en el nostre corpus unitats fraseològiques bastant recurrents per esdevenir marques clares d'estil, ja que les més recurrents són molt gramaticalitzades i s'expliquen sobretot per altres raons (gènere narratiu). 


\section{UNITATS FRASEOLÒGIQUES I ORALITAT FICCIONAL EN L'OBRA DE CU- CARELLA}

L'interés pel lèxic de la Costera és una constant en l'obra de Toni Cucarella. No hem trobat diferències quantitatives remarcables en l'ús d'unitats fraseològiques entre les distintes obres considerades, depenent de la data de publicació. La major part de les obres analitzades presenten un narrador en primera persona que, al seu torn, és un personatge de la novel·la. Per tant, s'observa que les unitats fraseològiques que serveixen per a evocar l'oralitat són presents tant en les parts narratives com en les dialogals.

Presentem tot seguit sengles taules amb l'ús de les unitats fraseològiques en les parts narratives (taula 4) per oposició a les dialogals (taula $5^{28}$ ).

Taula 4. Narració

\begin{tabular}{|l|l|}
\hline Locucions verbals & 255 \\
\hline Locucions nominals & 39 \\
\hline Locucions adjectives & 30 \\
\hline Locucions adverbials & 291 \\
\hline Refranys & 10 \\
\hline
\end{tabular}

Taula 5. Diàleg

\begin{tabular}{|l|l|}
\hline Locucions verbals & 253 \\
\hline Locucions nominals & 42 \\
\hline Locucions adjectives & 41 \\
\hline Locucions adverbials & 120 \\
\hline Refranys & 45 \\
\hline
\end{tabular}

Cal destacar la importància de l'ús de les unitats fraseològiques en el diàleg, ja que en valorar les xifres presentades s'ha de tenir en compte que el diàleg ocupa molta menys extensió en les obres buidades. Per exemple, pel que fa a les locucions verbals, nominals i adjectives, les xifres són molt pròximes en la narració i els diàlegs, però això implica una marcada presència d'unitats fraseològiques en els diàlegs. En canvi, la importància de complements circumstancials que modifiquen el verb en la narració pot explicar la diferència entre les locucions adverbials emprades en la narració (291) i les que s'usen en el diàleg (120), a més del fet que les parts narratives són molt més extenses que els diàlegs, com hem dit. També és un clar reflex de la llengua oral en els diàlegs l'ús dels refranys: trobem 45 refranys en els diàlegs, mentre que en la narració en trobem només 10.

A continuació, ens centrem en les unitats fraseològiques més recurrents, a saber, les locucions verbals, les locucions adverbials i els refranys. Fet i fet, el grau d'evocació de l'oralitat possiblement té a veure amb la tradició que puga presentar una unitat fraseològica en diversos gèneres textuals. Intuïtivament, podem pensar que determinades unitats fraseològiques resultarien força inadequades en textos molt formals, però no ho serien tant en d'altres de formals,

28 Les xifres no coincideixen amb les de la taula 1 perquè hi ha unitats fraseològiques que es repeteixen en la narració i el diàleg i, per tant, les hem comptabilitzades un nombre major de vegades en les taules 4 i 5. 
però més modalitzats, amb major presència de la subjectivitat del parlant (assaig, articles d'opinió) i en què és més admissible l'evocació de l'oralitat. Això de banda, és important el diferent grau de normalització d'una llengua i la producció i difusió de textos que pertanyen a diversos gèneres textuals. En aquest sentit, Cucarella (2002) conta una anècdota que considerem rellevant. Els correctors li van corregir el títol d'un article d'opinió, "El pacte per la llengua o tirar la llengua a pacte" (Cucarella 1998), per tal com no entengueren el joc de mots motivat per l'ús de la locució tirar a pacte 'llançar a perdre', procedent del món rural, concretament del tir de colom. Actualment es troba atestada en el $D N V$ i en MAR. Una unitat fraseològica col·loquial que no compte amb tradició en gèneres discursius formals evocaria en major mesura la llengua col·loquial justament per l'absència d'altres tipus de textos.

Les unitats fraseològiques que contribueixen a l'oralitat ficcional manifesten una marca diafàsica (col·loquial o vulgar). A més a més, moltes són dialectals. Finalment, com ja hem assenyalat, nombroses unitats fraseològiques tenen una connotació eminentment subjectiva, característica que les fa adients per al registre col·loquial $i$, en conseqüència, per a la imitació d'aquest, que trobem en els diàlegs, però també en la narració en primera persona. Així, arribar a misses dites (6) significa 'fer tard' (DNV, DCVB); parlar de naps i entendre cols vol dir 'no entendre correctament les paraules'(MAR, dir cols i entendre naps). No està atestat no saber on li cau la càrrega ('ser inconscient'), també ostensiblement col·loquial. L'acumulació d'unitats fraseològiques en (6) contribueix a intensificar la negativitat de la descripció del personatge, al temps que s'evoca la llengua parlada i el text adquireix un to marcadament subjectiu (modalitzat), ja que són metafòriques.

(6) Estava fet d'eixa pasta dels qui arriben sempre a misses dites i els parles de naps i entenen cols; a tothora embajocat, sense saber mai aon li cauia la càrrega. (LVT, p. 69)

Tant en (7) com en (8), la presència destacada del jo, en primera posició de la intervenció, tiny de subjectivitat els textos. Les locucions verbals fer a banderes (DNV: 'destrossar-la, fer-la malbé') i menjar-se les mans a mossos ( $D N V$ : 'tindre gran nerviosisme i inquietud') són igualment col·loquials i dialectals (7). Aquestes unitats fraseològiques metafòriques pertanyen a un camp semàntic (o domini cognitiu) que evoca la destrucció interior i la violència, dotant així de cohesió la intervenció: fer a banderes (destrucció, desmembració) i menjar-se les mans a mossos (acció violenta i, per tant, dany a la imatge pública de l'emissor ${ }^{29}$ ). A més, són locucions metafòriques i hiperbòliques.

(7) Jo, que sóc una persona i prou, se'm fa el cor a banderes de vore tanta mort sense sentit, i em menge les mans a mossos de no poder fer res per evitar tanta desgràcia. ( $C V$, p. 25)

En el fragment de (8) hi trobem diverses unitats fraseològiques de caràcter clarament col·loquial, no sols locucions verbals: a la dula (DNV: 'amb total llibertat, sense control o vigilància de ningú'), fer fugina ${ }^{30}$, guanyar la partida, traure a ballar ${ }^{31}$, a bacs $i$ a redolons (DNV: 'de

29 D’acord amb Penadés (2013), un dels criteris que ens poden ajudar a la marcació diafàsica de les locucions és el dany a la imatge pública de l'emissor, el receptor o la tercera persona que implica el significat literal de la locució en qüestió, d'acord amb la teoria de la cortesia de Brown i Levinson (1987). Sobre aquesta qüestió cf. també Sancho (2019).

30 Fer fugina és una locució verbal que el $D N V$ defineix com 'Deixar d'assistir allà on cal anar, com ara a escola o a complir un encàrrec.' També l'atesta, amb una definició semblant, el DCVB.

31 Traure la fam a ballar (a algú), segons el $D N V$, és una locució verbal que significa 'patir molta fam'. 
mala manera'); ací caic, allà m'alce ('ensopegant'), llenya entre cap i coll ${ }^{\beta 2}$. Des d'un punt de vista semàntic, la major part d'aquestes unitats fraseològiques són metafòriques (ací caic, allà m'alce; guanyar la partida, llenya entre cap i coll), i, a més, algunes d'elles impliquen també violència ( $a$ bacs $i$ a redolons, llenya entre cap $i$ coll). A més a més, en algunes d'elles es troben mots poc o gens coneguts fora de la unitat fraseològica en qüestió -mots isolats ${ }^{33}$ - (dula, fugina), de manera que aquestes unitats fraseològiques són força idiomàtiques. L'acumulació d'unitats fraseològiques en (8) contribueix clarament a la col·loquialització del text.

(8) I jo em crie a la dula i moltes voltes faig fugina d'escola, perquè a escola només ensenyen badomies que no servixen per a enfrontar-se amb la vida i guanyar-li la partida a la misèria que mos trau a ballar, i que ni ballar-la podem, que mos du a bacs i a redolons, ací caic, allà m'alce, i quan t'alces, llenya entre cap i coll. .. ( $Q L A$, p. 80$)$

Igualment, comptem amb nombroses locucions adverbials amb una marca diafàsica col-loquial que serveixen per evocar l'oralitat en els diàlegs: a grapats (DNV: 'en abundància', cf. (9)). A manta ( $D N V$ : 'en abundància') és col-loquial i dialectal (10). També és fortament col·loquial a més no poder (11). A grapats, semànticament, presenta una metàfora $\mathrm{i}$ una hipèrbole; manta ${ }^{34}$ és un mot isolat $\mathrm{i}$ la locució a manta presenta un cert grau de gramaticalització, cosa que explicaria la relativa recurrència que presenta $(7$ recurrències en el nostre corpus).

(9) “Jo t'explicaré", li va dir Montell, "com guanyar diners de veritat, a grapats"... (QLA, p. 132)

(10) Tenia mala fama, Celestí Llobell: denunciava a manta, te'n recordes?, tant si havies furtat com si no. $(C V$, p. 168$)$

(11) Estava espantat. Espantat a més no poder... I ja no volia morir-me... (UP, p. 70)

Pel que fa als refranys, també evoquen l'oralitat, si bé no són en absolut exclusius de la llengua ora ${ }^{35}$. Cucarella en presenta un ús abundós. Els refranys manifesten polifonia, ja que se cita la saviesa de les nacions (Gréssillon i Maingueneau 1984; Corpas 1996) i tenen diverses funcions discursives, però majorment important és la funció argumentativa (Conca 1996; Penadés 2006; Conca 2005). Així, a propòsit dels refranys emprats per Enric Valor, Conca (1996) assenyala el següent:

Amb categoria de textos, hi trobem inserits proverbis o refranys, que són unitats fraseològiques que tenen autonomia significativa completa, tot i que la seva funció lingüística es realitza en ser intextualitzats en situacions discursives diverses, on funcionen com a

32 El DNV recull entre cap i coll i defineix la locució adverbial com 'en la base del crani'.

33 Els mots diacritics (Corpas 1996) o isolats (Veny 1991) són mots atestats només a l'interior d'una unitat fraseològica. Per tant, els parlants només els atribueixen un significat a l'interior de la unitat fraseològica en qüestió i aquestes unitats fraseològiques esdevenen força idiomàtiques.

34 Tot i ser un quantificador indefinit (manta, mantes), segurament no és gaire conegut en aquest ús en els parlars valencians.

35 Penadés (2006), a partir de l'anàlisi de corpus orals col·loquials, considera que la freqüència hi és relativament baixa, com hem dit. Sobre la disminució en l'ús de refranys i les seues causes, es pot consultar també Corpas (1996) i Sancho (1999). 
veritables actes de parla, amb una intenció comunicativa de consell, d'imprecació, de constatació, d'exemple... i on es posa en joc les seves múltiples possibilitats significatives, gràcies, en part, al seu valor metafòric. (1996: 54)

Pocs refranys són recurrents, però són molt prominents cognitivament, en la mesura que constitueixen actes de parla associats a determinades situacions comunicatives (marcs of frames) $\mathrm{i}$ tot sovint presenten al seu interior metàfores i altres figures retòriques semàntiques $\mathrm{i}$ formals. En presentem alguns exemples en els diàlegs que contribueixen a recrear l'oralitat. A (12), Cadascú en sa casa sap on es penja el cresol 'Tothom coneix bé els assumpte que li atanyen', de caràcter metafòric. A (13) s'empren dos refranys: Els nebots peguen bots i Tots d'un ventre i cadascú de son temple. El significat del primer és, a parer nostre, opac, si bé és un significat negatiu; la rima delata la seqüència com a refrany. En relació amb el darrer, que el $D N V$ considera locució oracional ${ }^{36}$, aquest diccionari recull Tots d'un ventre $i$ cadascú de son temple i en diu: 'S'usa per a indicar que encara que siguen germanes, les persones són molt diferents entre elles'. La metàfora i la rima caracteritzen aquest refrany.

(12) A pesar que li ho advertien, Saurina no es contenia la llengua.

-No claves bací, Saurina. Cadascú en sa casa sap on es penja el cresol. (CV, p. 107)

(13) -Calvo Sotelo?

-Qui altre, sinó! Sembla mentida que porte la sang i els cognoms de l'immortal i màrtir José Calvo Sotelo. Una vergonya... Nebot seu, és. Els nebots peguen bots... -se'n va plànyer amb acritud.

-Tots d'un mateix ventre i cada u d'un temple... -va referir una altra sentència Maties Sorell, sense capficar-s'hi gens. (UP, p. 48)

En alguns casos la recurrència del refrany és pertinent, tot i que és baixa, perquè es dona en una mateixa obra, i de vegades fins i tot en una certa proximitat. La repetició del refrany Borinot ros, pesarós; negre, ull alegre... origina una isotopia ${ }^{37}(3$ ocurrències, cf. (14-16), en $U P$, la primera al principi de l'obra, les altres dues al final). D'aquesta manera, la recurrència del refrany serveix per a dotar de cohesió (i coherència) el text $i$, sobretot, reforçar l'estructura circular de la novel·la, connectant la primera mort del personatge principal (falsa) i la mort definitiva ${ }^{38}$. De més a més, el refrany inclou un saber zoològic popular, de caràcter supersticiós, i compta amb dues rimes ${ }^{39}$.

(14) Li ve al pensament el popular auguri que els atribueix la gent: "Borinot ros, pesarós; negre, ull alegre..." (UP, p. 13)

(15) Li va venir al pensament el popular auguri que els atribueix el comú de la gent: "Borinot ros, pesarós; negre, ull alegre...” (UP, p. 135)

(16) Maties Sorell va remugar i va recordar amb preocupació l'auguri de desgràcia: "Borinot ros, pesarós." (UP, p. 136)

36 El $D N V$ considera els refranys com a locucions oracionals.

37 Entenem isotopia en el sentit de Rastier (1976): “[...] tota iteració d'unitat lingüística [...]”, citat en Salvador (1986).

38 El narrador en primera persona és la mort en aquesta novel·la, omnipresent en tot el relat.

39 En totes dues escenes apareix un borinot, signe de mal averany. 


\section{CONCLUSIONS}

Com a conclusions del nostre treball, d'entrada, el corpus analitzat conté una presència destacada d'unitats fraseològiques, si comparem el seu nombre amb algunes dades procedents de corpus orals; al mateix temps, la presència d'unitats fraseològiques és moderada. En tot cas, independentment de la recurrència, són unitats prominents cognitivament, que destaquen sobre el discurs general pel seu caràcter fixat, institucionalitzat i tot sovint idiomàtic. A més, es tracta d'unitats fraseològiques variades (poques unitats fraseològiques són recurrents). Aquesta presència d'unitats fraseològiques no necessàriament reflecteix una recurrència comparable en la llengua col·loquial real. De fet, altres estudis realitzats sobre corpus orals reals demostren més aviat una presència escassa (Penadés 2004; Núñez 2016).

$\mathrm{La}$ recurrència d'una unitat fraseològica amb una marca diafàsica (informal $\mathrm{o}$ col·loquial, o vulgar) o diatòpica (unitats fraseològiques dialectals) determinades contribueix a l'oralitat ficcional del relat i, de fet, la major part de les unitats fraseològiques trobades apareixen en diàlegs $i$, en menor mesura, en la narració en primera persona: calfar-se el cap, pegar a fugir, traure a una vora, fill de puta, de mala veta, $i$ tot, etc. A més a més, trobem amb una recurrència important certes unitats fraseològiques que pertanyen a l'estàndard i són neutres quant al registre. Aquesta recurrència en ocasions es troba en unitats fraseològiques poc prototípiques, tal com s'ha demostrat en altres treballs (Penadés 2004): saber greu, estimar-se més, etc. ja que són semiidiomàtiques i presenten una fixació relativa (admeten la introduccio de constituents: saber molt de greu, estimar-se molt més). A més, no posseeixen una connotació expressiva. Per aquestes raons, possiblement no són prominents cognitivament per al lector. Finalment, la recurrència de certes unitats fraseològiques és esperable en un gènere discursiu com és la narrativa, on és especialment pertinent la introducció d'accions o la modificació d'aquestes per tal com les seqüències narratives presenten una marcada presència de verbs d'acció (mitjançant complements circumstancials de manera, temps, etc): de seguida, tot seguit, tot d'una, de sobte, de tant en tant, etc.

Per acabar, quant a la relació entre les unitats fraseològiques i l'oralitat ficcional, hem observat com determinades locucions verbals, locucions adverbials, amb una marca diafàsica col·loquial o vulgar, així com els refranys evoquen l'oralitat en els diàlegs i, en menor mesura, en la narració en primera persona.

\section{REFERÈNCIES BIBLIOGRÀFIQUES}

\section{Obres citades}

Briz, A. (1998). El español coloquial en la conversación. Esbozo de pragmagramática. Barcelona: Ariel.

Brown, P. i Levinson, S. C., (1987). Politeness: some universals in language usage. Cambridge: Cambridge University Press. https://www.academia.edu/26395652/Politeness_Some_universals_ in language usage

Brumme, J. (ed.) (2008). La oralidad fingida: descripción y traducción. Teatro, cómic y medios audiovisuales. Madrid / Frankfurt del Meno: Iberoamericana / Vervuert.

Brumme, J. i Resinger, H. (eds.) (2008). La oralidad fingida: obras literarias. Descripción y traducción. Madrid / Frankfurt del Meno: Iberoamericana / Vervuert. 
Brumme, J. i Espunya, A. (2012). "Background and justification: research into fictional orality". En Brumme, J. i A. Espunya, (eds.). The translation of fictive dialogue. Amsterdam / Nova York: Rodopi, pp. 7-31.

Burger, H. (2010 [1998 1a ed.]). Phraseologie. Eine Einführung am Beispiel des Deutschen (4a edició revisada). Berlín: Erich Schmidt.

Conca, M. (1996). "La riquesa fraseològica en la producció rondallística d'Enric Valor". Simposi d'Estudi i Festa. Diputació d'Alacant: Ingra impressors, pp. 47-59.

Conca, M. (2005). "Les unitats fraseològiques en el discurs argumentatiu", Articles de didàctica de la llengua i de la literatura, 36, pp. 32-42.

Conca, M. i Guia, J. (2014). La fraseologia. Principis, mètode i aplicacions. Alzira: Bromera / Institut Interuniversitari de Filologia Valenciana.

Corpas, G. (1996). Manual de fraseología española. Madrid: Gredos.

Coseriu, E. (1994 [1980 1a edició]). Textlinguistik. 3a edició revisada per Jörn Albrecht. Múnic: Wilhelm Fink.

Cucarella, T. (1998). "Papers antics: el pacte per la llengua o tirar la llengua a pacte". La llengua a pacte, pp. 2-4: https://blocs.mesvilaweb.cat/cucarella/wp-content/uploads/sites/1575/2014/08/Lallengua-a-pacte-Toni-Cucarella.pdf (6-9-2018)

Cucarella, T. (2002). "Llengua col·loquial, llengua literària". En Casanova, E., J. Martí i A. Saragossà (eds.). Estudis del valencià d'ara. Paiporta: Denes, pp. 123-130.

Cuenca, M.J. (2008). Gramàtica del text. Alzira: Bromera / Institut Interuniversitari de Filologia Valenciana

Cuenca, M. J. (2011). “Catalan interjections”. En Cots, J. M. i L. Payrató (eds.). The pragmatics of Catalan. Berlín / Boston, De Gruyter, 173-211.DOI: https://doi.org/10.1515/9783110238693

Ferrer, M. i Salvador, V. (2005). "Fraseologia i educació discursiva", Articles de didàctica de la llengua i de la literatura, 36, pp. 5-11.

Fleischer, W. (1997 [1982 1a edició]). Phraseologie der deutschen Gegenwartssprache (2a edició revisada). Tubinga: Max Niemeyer.

García-Page, M. (2008). Introducción a la fraseología española. Estudio de las locuciones. Barcelona: Anthropos.

Gréssillon, A. i Maingueneau, D. (1984). "Polyphonie, proverbe et détournement”, Langages, 73, pp. 112-125. https://www.persee.fr/doc/lgge_0458-726x_1984_num_19_73_1168

Hanks, P. (2000): "Dictionaries of idioms and phraseology in English”. En Corpas, G. (ed.). Las lenguas de Europa: estudios de fraseología, fraseografía y traducción. Granada: Comares, pp. 303-320.

Jakobson, R. (1964). Lingüistica i poètica i altres assaigs. Barcelona: Edicions 62.

Koch, P. \& Oesterreicher, W. (1990). Gesprochene Sprache in der Romania. Berlín / Nova York: De Gruyter.

Koch, P. \& Oesterreicher, W. (2007). Lengua hablada en la Romania: español, francés, italiano. Madrid: Gredos.

Levinson, S. (2004 [2000 1a edició]). Significados presumibles: la teoría de la implicatura conversacional generalizada. Madrid: Gredos.

Lorente, M. (2002). “Altres elements lèxics”. En Solà, J., M. R. Lloret, J. Mascaró i M. Pérez (dirs.). Gramàtica del català contemporani. Barcelona: Empúries, vol. 1, pp. 831-887.

Luque, J. de D. (2005): "Las colocaciones de cuantificación por comparación: tradición e innovación en las comparaciones proverbiales". En Luque, J. de D. i A. Pamies (eds.). La creatividad en el lenguaje: colocaciones idiomáticas y fraseología. Granada: Granada Lingvistica, pp.409-456.

Núñez, Z. (2016). Las fórmulas oracionales en español coloquial. Alcalá de Henares: Universidad de Alcalá de Henares (tesi doctoral). https://ebuah.uah.es/dspace/handle/10017/26459

Oesterreicher, W. (2004). "Textos entre inmediatez y distancia comunicativas: el problema de lo hablado escrito en el Siglo de Oro". En Cano, R. (ed.). Historia de la lengua española. Barcelona: Ariel, pp. 729-769. 
Payrató, L. (1990 [1988, 1a ed.]). Català col-loquial. Aspectes de l'ús corrent de la llengua catalana. València: Universitat de València.

Penadés, I. (2004). “¿Caracterizan las locuciones el registro coloquial?”. En Villayandre, M. (ed.). Actas del V Congreso de Lingüística General, León, 5-8 de marzo de 2002. Madrid: Arco/Libros, 3 vol., pp. 2225-2235.

Penadés, I. (2006). "El valor discursivo de los refranes", Estudios de Lingüistica de la Universidad de Alicante, 20, pp. 287-304. DOI: https://doi.org/10.141198/ELUA2006.20

Penadés, I. (2013). "La imagen subyacente a las locuciones como criterio de marcación diafásica". En Olza, I. i E. Manero (eds.). Fraseopragmática. Berlín: Frank \& Timme, pp. 23-48. https:// books.google.es/books?id=XGQVAgAAQBAJ\&pg=PA23\&lpg=PA23\&dq=\%E2\%80\%9CLa+im agen+subyacente $+a+$ las + locuciones + como + criterio + de + marcaci $\% \mathrm{C} 3 \% \mathrm{~B} 3 \mathrm{n}+\mathrm{diaf} \% \mathrm{C} 3 \% \mathrm{~A} 1$ sica $\%$ E2\%80\%9D.\&source $=$ bl\&ots $=$ d5oVn_kh-D\&sig=ACfU3U0Gq8oRhJuYMB8gzxXb2anN0bww0 $\mathrm{g} \& \mathrm{hl}=\mathrm{es} \& \mathrm{sa}=\mathrm{X} \& \mathrm{ved}=2 \mathrm{ahUKEwiNituYhuzoAhVKQBoKHcijAuUQ6AEwA3oECAsQLw \# v=on}$ epage $\& \mathrm{q}=\% \mathrm{E} 2 \% 80 \% 9 \mathrm{CLa} \% 20$ imagen $\% 20$ subyacente $\% 20 \mathrm{a} \% 20 \mathrm{las} \% 20$ locuciones $\% 20$ como $\% 20$ criterio $\% 20 \mathrm{de} \% 20$ marcaci $\% \mathrm{C} 3 \% \mathrm{~B} 3 \mathrm{n} \% 20 \mathrm{diaf} \% \mathrm{C} 3 \% \mathrm{~A} 1$ sica $\% \mathrm{E} 2 \% 80 \% 9 \mathrm{D} . \& \mathrm{f}=$ false

Piquer, A. (2000). "Pragmàtica de la fraseologia del relat". En Salvador, V. i A. Piquer (eds.). El discurs prefabricat. Estudis de fraseologia teòrica i aplicada. Castelló de la Plana: Universitat Jaume I, pp. 389-407.

Piquer, A. (2005). "Fraseologia i literatura. El discurs reciclat", Articles de didàctica de la llengua $i$ de la literatura, 36, pp. 56-64.

Piquer, A. i Martín, À. (2006). "Ús de la fraseologia: contrast i capgirament de registres". En Salvador, V. i L. Climent (eds.). El discurs prefabricat II: Fraseologia i comunicació social. Castelló de la Plana: Universitat Jaume I, pp. 303-317.

Richter-Vapaatalo, U. (2007). Da hatte das Pferd die Nüstern voll. Gebrauch und Funktion von Phraseologie im Kinderbuch. Frankfurt del Meno: Peter Lang.

Ruiz, L. (1996). "Sobre la fraseología coloquial: corpus e investigación”. En Gutiérrez, F. (ed.). El español, lengua Internacional (1492-1992). I Congreso Internacional de AESLA, Granada, 23-26 de septiembre de 1992. Murcia: AESLA, pp. 493-498.

Salvador, V. (1986). El gest poètic. Cap a una teoria del poema. València: Universitat de València / Institut de Filologia Valenciana / Publicacions de l'Abadia de Montserrat. 2a edició.

Salvador, V. (1995). "De la fraseologia a la lingüística aplicada", Caplletra, 18, pp. 11-30. https://ojs. uv.es/index.php/caplletra/article/view/7381/6989

Sancho, P. (1999). Introducció a la fraseologia. Aplicació al valencià col-loquial. Paiporta: Denes.

Sancho, P. (2017). "Les fórmules oracionals i l'oralitat ficcional en la narrativa de Toni Cucarella", Journal of Catalan Studies, 20, pp. 64-99. http://jocs.anglo-catalan.org/ojsnew/index.php/jocs/ article/view/24/25

Sancho, P. (2019). "Fraseologia i variació: Algunes reflexions a propòsit de l'obra de Toni Cucarella", Catalan Review, 33, pp. 55-77. DOI: 10.3828/CATR.33.4

Schellheimer, S. (2016). La función evocadora de la fraseología en la oralidad ficcional y su traducción. Berlín: Frank \& Timme.

Timofeeva, L. (2012). El significado fraseológico. En torno a un modelo explicativo y aplicado. Madrid: Liceus.

Tristá, M. (1988). Fraseología y contexto. L'Havana: Ciencias sociales.

Veny, J. (1991). Mots d'ahir i mots d'avui. Barcelona: Empúries.

Vigara, A. M. (1992). Morfosintaxis del español coloquial. Esbozo estilístico. Madrid: Gredos.

Zuluaga, A. (1997). "Sobre las funciones de los fraseologismos en textos literarios", Paremia, 6, pp. 631-640. 


\section{Corpus}

Cucarella, T. (1997). La lluna vista des de la terra. Barcelona: Columna. (sigla LVT)

Cucarella, T. (1998). L'última paraula. Barcelona: Columna. (sigla UP)

Cucarella, T. (2002). Els camps dels vençuts. Barcelona: Columna. (sigla CV)

Cucarella, T. (2003). Quina lenta agonia, la dels ametlers perduts. València: 3 i 4. (sigla QLA)

\section{Diccionaris}

Acadèmia Valenciana de la Llengua (2016). Diccionari normatiu valencià. València: Acadèmia Valenciana de la Llengua. [en línia: http://www.avl.gva.es/lexicval/ (consulta: gener de 2019)] (sigla $D N V$ )

Alcover, Joan i Francesc de Borja Moll. Diccionari català-valencià-balear. Palma de Mallorca: Moll. [en línia: http://dcvb.iecat.net/ (consulta: juliol de 2017)] (sigla DCVB)

Institut d'Estudis Catalans. Diccionari de la llengua catalana. [en línia: https://dlc.iec.cat/ (consulta: març de 2020)] (sigla DIEC)

Espinal, M. T. (2004). Diccionari de sinònims de frases fetes. Barcelona: Universitat Autònoma de Barcelona / Publicacions de la Universitat de València / Publicacions de l'Abadia de Montserrat. [en línia: https://dsff.uab.cat/ (consulta: gener de 2019)] (sigla ESP)

Martí, J. (2017). Diccionari de fraseologia (segles XVII-XXI). València: Universitat de València / Acadèmia Valenciana de la Llengua / Institució Alfons el Magnànim / Universitat d'Alacant. (sigla $M A R$ ) 